\title{
64. Further Studies of the Chromosomes of the Labridae (Pisces)
}

\section{A Preliminary Note}

\author{
By Yoshio OJIma and Eiji KashiwagI \\ Department of Biology, Faculty of Science, \\ Kwansei Gakuin University, Nishinomiya \\ (Communicated by Sajiro Makino, M. J. A., June 12, 1980)
}

Recent advances in cytogenetics have provided evidence indicating that evolutional changes in organisms have arisen first as changes in the chromosomes. It is then approval for that cytogenetic data serve as worthwhile tool for the analysis of the systematic differentiation of the organism in general. This article deals with the chromosomal features of 30 species of labrid fishes in relation to their systematic differentiation.

The members of the Japanese Labridae are represented by four subfamilies, consisting of 28 genera and 94 species.

The specimens used for this study were partly obtained in the Kushimoto Marine Park, Wakayama Prefecture, and partly collected at Kuroshima in the Yaeyama Group of Ryukyu Islands.

Following the technique previously described (Ojima and Kashiwagi, 1979), kidney tissues were predominantly used for chromosome study: The tissues after colchicine- $\mathrm{KCl}$ pretreatments were fixed in Carnoy-solution and Giemsa-stained.

The karyotypes established in the 30 species are described according to the arrangement in three subfamilies (cf. Table I).

Bodianinae: As shown in Table I, three species of Bodianus were chromosomally studied. All species under study were found to possess uniformly 48 chromosomes in $2 n$. In spite of the same number of chromosome, each species was remarkable by different karyotypes as well as by NF 'nombre fondamental'. The karyotypic structure in each are as seen in Table I. Interesting is the presence of 8 metacentrics in all species in contrast to the different numbers of other types of chromosomes (Fig. 1).

Corinae: The chromosomes of 22 species of Corinae were studied. All the species showed uniformly 48 chromosomes, though they were characterized by different karyotypes. Remarkable is the fact that, though the numbers were not exactly the same, the ST or A chromosomal elements were predominant in occurrence in the complement of each species, while the M or SM were very less or zero 
in occurrence (see Table I). On this basis, therefore, the NF value was rather close or nearly allied (Figs. 2-5).

Table I. The chromosome numbers and karyotypes established for 30 species of Labridae

\begin{tabular}{|c|c|c|c|c|c|c|}
\hline & $\mathrm{CN}$ & M & SM & ST, A & $\mathrm{NF}$ & $\begin{array}{l}\text { No. of } \\
\text { specimens }\end{array}$ \\
\hline \multicolumn{7}{|l|}{ Bodianinae } \\
\hline Bodianus axillaris & 48 & 8 & 30 & 10 & 86 & 1 \\
\hline Bodianus loxozonus & 48 & 8 & 26 & 14 & 82 & 1 \\
\hline Bodianus mesothorax & 48 & 8 & 18 & 22 & 74 & 3 \\
\hline \multicolumn{7}{|l|}{ Corinae } \\
\hline Cheilio inermis & 48 & 12 & 12 & 24 & 72 & 3 \\
\hline Gomphosus varius & 48 & 0 & 0 & 48 & 48 & 2 \\
\hline Thalassoma lunare & 48 & 0 & 0 & 48 & 48 & 3 \\
\hline Thalassoma lutescens & 48 & 0 & 0 & 48 & 48 & 3 \\
\hline Thalassoma quinquevittata & 48 & 0 & 0 & 48 & 48 & 4 \\
\hline Thalassoma cupid & 48 & 0 & 0 & 48 & 48 & 10 \\
\hline Thalassoma amblycephala & 48 & 0 & 0 & 48 & 48 & 6 \\
\hline Pseudolabrus japonicus & 48 & 2 & 2 & 44 & 52 & 5 \\
\hline Labroides dimidiatus & 48 & 0 & 0 & 48 & 48 & 4 \\
\hline Stethojulis interrupta & 48 & 0 & 2 & 46 & 50 & 9 \\
\hline Stethojulis bandanensis & 48 & 4 & 0 & 44 & 52 & 17 \\
\hline Stethojulis strigiventer & 48 & 2 & 0 & 46 & 50 & 2 \\
\hline Halichoeres trimaculatus & 48 & 0 & 0 & 48 & 48 & 28 \\
\hline Halichoeres centriquadrus & 48 & 0 & 0 & 48 & 48 & 4 \\
\hline Halichoeres prosopeion & 48 & 2 & 0 & 46 & 50 & 1 \\
\hline Halichoeres poecilopterus & 48 & 4 & 2 & 42 & 54 & 6 \\
\hline Halichoeres kallochroma & 48 & 0 & 0 & 48 & 48 & 6 \\
\hline Halichoeres melanochir & 48 & 0 & 2 & 46 & 50 & 3 \\
\hline Halichoeres tenuispinnis & 48 & 0 & 2 & 46 & 50 & 7 \\
\hline Coris gaimardi & 48 & 2 & 10 & 36 & 60 & 2 \\
\hline Coris multicolor & 48 & 6 & 8 & 34 & 62 & 6 \\
\hline Hologymnosus semidiscus & 48 & 2 & 2 & 44 & 52 & 3 \\
\hline \multicolumn{7}{|l|}{ Cheilininae } \\
\hline Cirrhilabrus temminckii & 34 & 10 & 2 & 22 & 46 & 10 \\
\hline Cirrhilabrus cyanopleura & 34 & 10 & 2 & 22 & 46 & 13 \\
\hline Epibulus insidiator & 48 & 4 & 8 & 36 & 60 & 2 \\
\hline Hemipteronotus dea & 44 & 0 & 0 & 44 & 44 & 1 \\
\hline Cheilinus bimaculatus & 32 & 4 & 2 & 26 & 38 & 3 \\
\hline
\end{tabular}

CN : Chromosome number. M: Metacentric. SM: Submetacentric. ST, A: Subtelocentric or acrocentric. NF: Fundamental number (nombre fondamental).

Cheilininae: Five species came under chromosomal study (Table I). The chromosomes varied considerably in both number and morphology. The variation ranged from 32 to 48 in the $2 n$-number, and from 38 to 60 in NF. Karyotypically the variation was also remarkable, the number of M, SM and ST, A chromosomes being different by species (Figs. 6-9). 


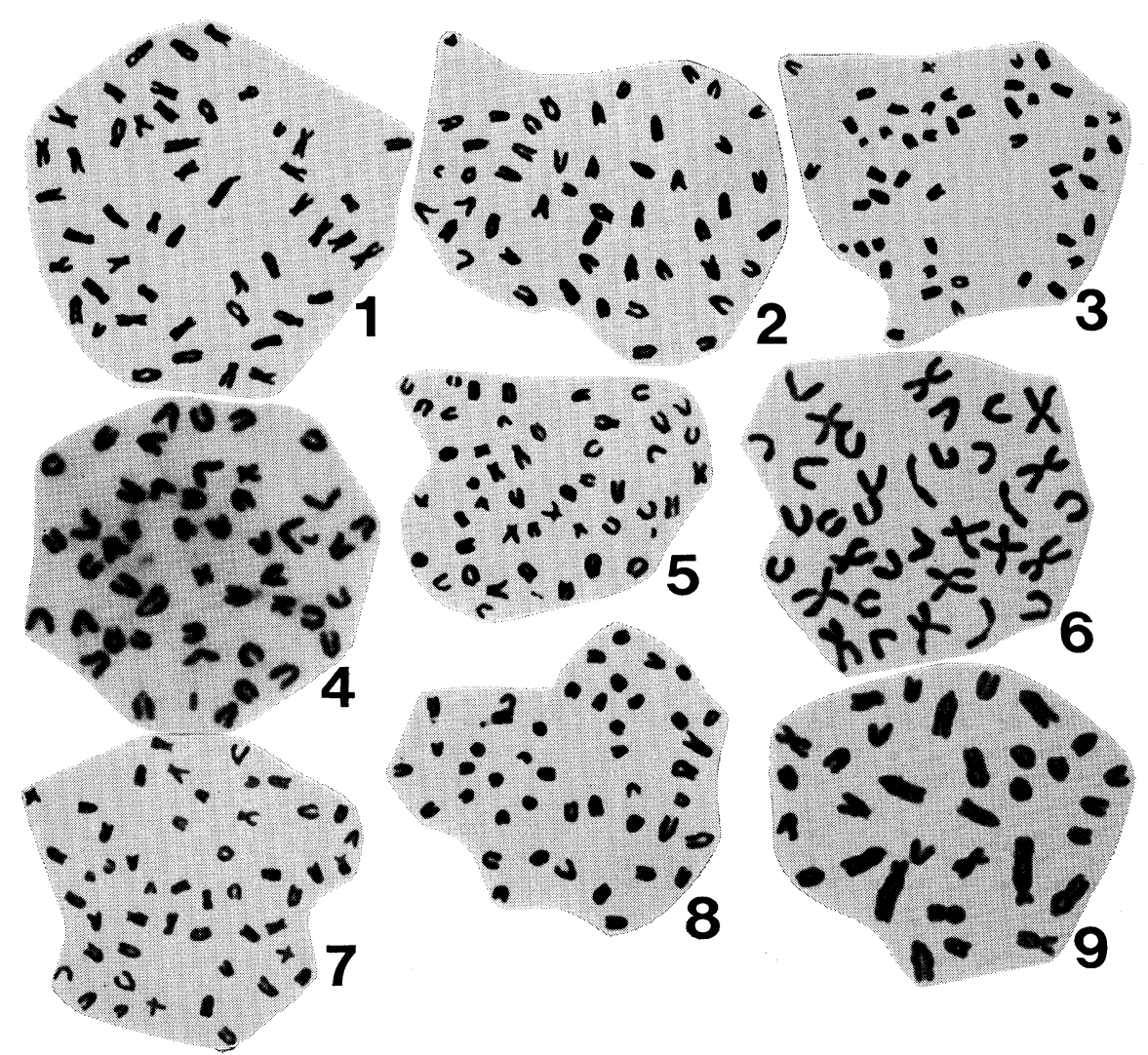

Fig. 1-9. Photomicrographs of metaphase chromosomes of nine species of Labrid fishes studied. 1: Bodianus axillaris. 2: Thalassoma lutescens. 3: Halichoeres prosopeion. 4: Psendolabrus japonicus. 5: Coris multicolor. 6: Cirrhilabrus temminckii. 7: Epibulus insidiator. 8: Hemipteronotus dea. 9: Cheilinus bimaculatus.

Remarks. Reviewing the statistical data of teleostean chromosomes, we can find the presence of some established trend in the chromosome numbers in relation to the evolutional process. According to Gosline (1971), the teleostean fishes were systematically classified into the following three larger groups: The lower group including Salmoniformes, Cypriniformes, etc.; the intermediate group represented by Cyprinodontiformes, etc.; and the higher group involving Perciformes, etc.

The Labridae belongs to Perciformes carrying the characteristics of the higher group. The noticeable picture in relation to the evolutional process especially from the intermediate to higher groups is a gradual concentration of the chromosome number into $2 n$, 48 , with a shift toward smaller numbers. Statistically, a general feature is that M or SM chromosomes are known to appear in the lower group, 
whereas ST or A chromosomes occur rather predominantly in the intermediate and higher groups.

So far as the present investigations have gone, the members of the Corinae were found to possess a chromosomal pattern typical to the higher group. The chromosome changes occurring in this subfamily would be derived from the ancestral type with 48 chromosomes through the mechanism of pericentric inversion (Ohno et al., 1969, 1974; Uyeno, 1972; Gold, 1977; Ojima and Kashiwagi, 1979; etc.). In contrast, the members of the Bodianinae and Cheilininae are out of the scope of the higher group in their karyological scheme. Numerically the chromosomes of the Bodianinae are within the category of the higher group, but their karyotypes and NF are of the lower group pattern. In the Cheilininae, both of the chromosome number and karyotype fall within the category of the lower group. It can be said that the evolutional mechanism of fishes has now been still within the concussive whirlwind of discussion.

Summary. The chromosomes of 30 species of the Labridae (Pisces) involving 3 species of the Bodianinae, 22 species of the Corinae and 5 species of the Cheilininae were comparatively studied. The chromosomal changes were remarked in relation to the evolutional relationship. Detailed accounts will be presented elsewhere in the near future.

Acknowledgements. We are very indebted to Dr. Sajiro Makino, M. J.A., Professor Emeritus, Hokkaido University, for improvement of the manuscript with critical revision of data. Our thanks are also expressed to the kindness of Dr. Uchida, the Sabiura Marine Park Research Station, Kushimoto for the facility of materials used for this study.

\section{References}

Gold, J. R. (1979) : Cytogenetics. Fish Physiology. vol. 8 (eds. W. S. Hoar, D. J. Randall and J. R. Brett), Academic Press, pp. 353-405.

Gosline, W. A. (1971) : Functional Morphology and Classification of Teleostean Fishes. University Press of Hawaii.

Ohno, S. (1974) : Chordata 1, Protochordata, Cyclostomata and Pisces. Animal Cytogenetics, 4, 1-92.

Ohno, S., J. Muramoto, J. Klein, and N. B. Atkin (1969) : Diploid-tetraploid relationship in clupeoid and salmonid fish. Chromosomes Today, 2, 139-147.

Ojima, Y., and E. Kashiwagi (1979): A karyotype study of eleven species of labrid fishes from Japan. Proc. Japan Acad., 55B, 280-285.

Uyeno, T. (1973): A comparative study of chromosomes in the teleostean fish order Osteoglossiformes. Japan. J. Ichthyology, 20, 211-217. 